\title{
Mitigation of cadmium and arsenic in rice grain by applying different silicon fertilizers in contaminated fields
}

\author{
Hong-Yan Wang ${ }^{1,2} \cdot$ Shi-Lin Wen ${ }^{3} \cdot$ Peng Chen $^{2} \cdot$ Lu Zhang $^{3} \cdot$ Kuang Cen $^{1}$ • \\ Guo-Xin Sun ${ }^{2}$
}

Received: 11 June 2015 / Accepted: 18 October 2015 /Published online: 24 October 2015

(C) Springer-Verlag Berlin Heidelberg 2015

\begin{abstract}
A field experiment was established to support the hypothesis that application of different silicon $(\mathrm{Si})$ fertilizers can simultaneously reduce cadmium (Cd) and arsenic (As) concentration in rice grain. The "semi-finished product of Si-potash fertilizer" treatment at the high application of $9000 \mathrm{~kg} / \mathrm{ha}(\mathrm{NP}+\mathrm{S}-\mathrm{KSi} 9000)$ significantly reduced the As concentration in rice grain by up to $20.1 \%$, compared with the control. Si fertilization reduces the $\mathrm{Cd}$ concentration in rice considerably more than the As concentration. All Si fertilizers apart from sodium metasilicate $\left(\mathrm{Na}_{2} \mathrm{SiO}_{3}\right)$ exhibited a high ability to reduce $\mathrm{Cd}$ concentration in rice grain. The $\mathrm{Si}$ calcium $(\mathrm{CaSi})$ fertilizer is the most effective in the mitigation of $\mathrm{Cd}$ concentration in rice grain. The $\mathrm{CaSi}$ fertilizer applied at $9000 \mathrm{~kg} / \mathrm{ha}(\mathrm{NPK}+\mathrm{CaSi} 9000)$ and $900 \mathrm{~kg} / \mathrm{ha}(\mathrm{NPK}+\mathrm{CaSi} 900)$ reduced the $\mathrm{Cd}$ concentration in rice grain about 71.5 and $48.0 \%$, respectively, while the Si-potash fertilizer at $900 \mathrm{~kg} /$ ha (NP+KSi900), the semi-finished product of Si-potash fertilizer at both $900 \mathrm{~kg} / \mathrm{ha}(\mathrm{NP}+\mathrm{S}-\mathrm{KSi} 900)$ and $9000 \mathrm{~kg} / \mathrm{ha}$ (NP+S-KSi9000), and the rice straw (NPK+RS) treatments reduced the Cd concentration in rice grain about $42,26.5$,
\end{abstract}

Responsible editor: Elena Maestri

Hong-Yan Wang and Shi-Lin Wen contributed equally to this work.

Guo-Xin Sun

gxsun@rcees.ac.cn

1 School of Earth Sciences and Resources, China University of Geosciences, Beijing 100083, China

2 State Key Laboratory of Urban and Regional Ecology, Research Center for Eco-Environmental Sciences, Chinese Academy of Sciences, Beijing 100085, China

3 National Engineering Laboratory for Improving Quality of Arable Land, Institute of Agricultural Resources and Regional Planning, Chinese Academy of Agricultural Sciences, Beijing 100081, China
40.7 , and $23.1 \%$, respectively. The results of this investigation demonstrated the potential effects of Si fertilizers in reducing $\mathrm{Cd}$ and As concentrations in rice grain.

Keywords Field experiment - Arsenic · Cadmium · Mitigation $\cdot$ Silicon fertilizer $\cdot$ Rice grain

\section{Introduction}

Rice (Oryza sativa L.) is a staple food that supports almost half of the world's population (Sun et al. 2012). Unfortunately, rice is also the major contributor to the human intake of the toxic trace elements such as cadmium (Cd) and arsenic (As) worldwide, especially in Asia (Meharg et al. 2009; Williams et al. 2009). Human exposure to As and Cd by means of daily consumption in food is a concern in many areas of China, where farming and mining coexist (Williams et al. 2009; Sun et al. 2012). Arsenic, especially inorganic form, is classified as a non-threshold class 1 human carcinogen and can cause serious health problems such as skin cancer and lung, bladder, kidney, and other diseases (Bernard and Lauwerys 1986; Ng et al. 2003; Halim et al. 2009). Cd has been linked to diseases including lung cancer, pulmonary adenocarcinomas, prostatic proliferative lesions, bone fractures, kidney dysfunction, and hypertension (Bernard and Lauwerys 1986).

Rice consumption is a major source of $\mathrm{Cd}$ and As for the global human population (Sun et al. 2008; Williams et al. 2009). Cd has relatively high mobility in paddy soil and can be easily absorbed into rice root using the same transport pathways as micronutrients such as $\mathrm{Fe}^{2+}, \mathrm{Zn}^{2+}$, and $\mathrm{Ca}^{2+}$ (Clemens 2006; Verbruggen et al. 2009; Clemens et al. 2013). Arsenic is particularly easily accumulated in rice grain compared with other cereals, because the bioavailability of As is markedly enhanced in flooded environments and the 
released As is absorbed into the rice root through silicic acid transporters, which are widely distributed in rice plants (Zhao et al. 2009). Contamination of As and $\mathrm{Cd}$ in rice grain may pose a risk to human health through the food chain. Thus, practical solutions are urgently needed to mitigate the accumulation of $\mathrm{Cd}$ and $\mathrm{As}$ in rice grain.

Various actions have been undertaken to reduce the uptake of $\mathrm{Cd}$ and $\mathrm{As}$ by rice. Evidence has suggested that silicon $(\mathrm{Si})$ fertilizers are effective in reducing the concentration of $\mathrm{Cd}$ (Shi et al. 2005; Kim et al. 2014) or As in rice grain (Guo et al. 2007; Seyfferth and Fendorf 2012). Various Si compounds, such as $\mathrm{K}_{2} \mathrm{SiO}_{3}$ and silica gel, were chosen as $\mathrm{Si}$ fertilizers for hydroponic culture or pot experiments to mitigate $\mathrm{Cd}$ or As individually in rice shoots (Zhang et al. 2008; Putwattana et al. 2010; Marmiroli et al. 2014). It can be difficult to compare the effects of various Si fertilizers on reducing $\mathrm{Cd}$ or As in rice because of the differences in fertilizer types, dosage, rice cultivation methods, and other confounding factors. In addition, most of the experiments in the previous studies were designed to investigate the reduction effect of single toxic metals such as As or Cd rather than both of them together. These toxic metals commonly coexist in the contaminated fields, especially in the paddy fields of Southern China, which are in the vicinity of large-scale mining or ore-processing facilities and are subject to irrigation water contaminated with multiple elements. About 65 and $50 \%$ of rice from fields that are impacted by the proximity of mines fail Chinese national food standards of As and Cd respectively, and most rice is cocontaminated (Williams et al. 2009). However, the effects of $\mathrm{Si}$ fertilizers on simultaneous mitigation of $\mathrm{Cd}$ and $\mathrm{As}$ in rice are as yet unclear.

The information from field experiments about $\mathrm{Si}$ for $\mathrm{Cd}$ and As reduction in rice grain is limited, even though many laboratory experiments have shown the efficacy of As and $\mathrm{Cd}$ reduction in rice grain by Si application (Wang et al. 2000; Zhang et al 2008; Guo et al. 2009). The field experiment is necessary to confirm the effects of Si fertilizers on heavy metal mitigation, especially in the paddy fields contaminated with multiple elements. Silicon fertilizers such as Si-calcium fertilizer and Si-potash fertilizer have been extensively applied in rice fields for increasing productivity (Ma et al. 2001; Meharg and Meharg 2015).

In this study, several Si fertilizers (Si-calcium fertilizer, Sipotash fertilizer, sodium metasilicate, semi-finished product of $\mathrm{Si}$-potash fertilizer) were chosen as $\mathrm{Si}$ sources to investigate their capacities of reducing $\mathrm{Cd}$ and As concentrations in rice grain. About $5-10 \%$ of $\mathrm{Si}$ exists in rice straw as phytolith which is a kind of amorphous $\mathrm{Si}$ (Marschner and Rimmington 1988). As a Si hyper-accumulator, rice straw can also be regarded as a type of Si fertilizer (Epstein 1994; Liang 1999; Ma et al. 2001) because of the higher solubility of amorphous $\mathrm{Si}(1.8-2.0 \mathrm{mM} \mathrm{Si})$ in rice straw than crystalline counterpart quartz (0.1-0.25 mM Si) (Drees et al. 1989; Fraysse et al.

2006). Considering the ubiquity of rice straw being returned to paddy fields, rice straw was also selected as a potential $\mathrm{Si}$ fertilizer to study its effect on reducing $\mathrm{Cd}$ and As concentrations in rice grain.

The aims of the present study were to investigate (1) the effect of Si fertilizers on reducing $\mathrm{Cd}$ and As concentration in rice grain in paddy field and (2) the relative efficacy of various $\mathrm{Si}$ fertilizers in reducing $\mathrm{Cd}$ and $\mathrm{As}$ concentrations at the same time.

\section{Materials and methods}

\section{Materials}

The field experiment was conducted in city of Qiyang (Hunan Province, China). The concentrations of some toxic elements in the study soil are listed in Table 1 . As and $\mathrm{Cd}$ concentrations slightly exceed the Chinese standard for agricultural land (30 mg/kg for As and $0.4 \mathrm{mg} / \mathrm{kg}$ for Cd) (GB15618-1995). The rice cultivar utilized in this study is Xiangfengyou 186.

\section{Methods}

The experiment was established using a completely randomized design with three replicates per treatment $(27$ plots in total). The area of each plot was $30 \mathrm{~m}^{2}$. The Si fertilizers used in the experiment were Si-potash fertilizer $(\mathrm{KSi}, 50 \%$ water soluble and $50 \%$ citrate soluble potassium), Si-calcium fertilizer (CaSi), a semi-finished product of Si-potash fertilizer (S$\mathrm{KSi}$, citrate soluble potassium), and sodium metasilicate $\left(\mathrm{Na}_{2} \mathrm{SiO}_{3}\right)$. Rice straw (RS) was also applied as a type of $\mathrm{Si}$ fertilizer in this study. Basal fertilizers supplied were nitrogen (N) $230 \mathrm{~kg} / \mathrm{ha}$ as urea, phosphorus (P) $625 \mathrm{~kg} / \mathrm{ha}$ as calcium superphosphate, and potassium (K) $150 \mathrm{~kg} / \mathrm{ha}$ as potassium chloride. All Si fertilizers were applied together with basal fertilizers onto the field before transplantation, and in the plots with $\mathrm{KSi}$ and $\mathrm{S}-\mathrm{KSi}$ fertilizers, no extra potassium chloride was applied as K fertilizer. Si fertilizers were applied at $900 \mathrm{~kg} / \mathrm{ha}$. Tillering fertilizers supplied before the tillering stage were $\mathrm{N} 100 \mathrm{~kg} / \mathrm{ha}$ as urea and $\mathrm{K} 50 \mathrm{~kg} / \mathrm{ha}$ as potassium

Table 1 The concentrations of toxic elements in soil $(\mathrm{mg} / \mathrm{kg})$

\begin{tabular}{lc}
\hline Toxic elements & $\mathrm{mg} / \mathrm{kg}$ \\
\hline $\mathrm{As}$ & $37.5 \pm 3.7$ \\
$\mathrm{Cu}$ & $26.6 \pm 5.7$ \\
$\mathrm{Mn}$ & $136.0 \pm 17.7$ \\
$\mathrm{~Pb}$ & $36.8 \pm 1.2$ \\
$\mathrm{Cd}$ & $0.4 \pm 0.04$ \\
$\mathrm{Zn}$ & $117.7 \pm 17.6$ \\
$\mathrm{Cr}$ & $71.8 \pm 7.2$
\end{tabular}


chloride. Six plots with tenfold additional CaSi and S-KSi fertilizers $(9000 \mathrm{~kg} / \mathrm{ha})$ were used to investigate the dose response of As and $\mathrm{Cd}$ accumulations in rice grain to Si fertilizer application. Control plots were established without fertilization. Rice was transplanted by hand and grown in flooded fields until maturity.

\section{Sampling and sample preparation}

The rice was planted in July 2014 and harvested in October 2014. After maturation, four intact rice plants were randomly collected from every plot. The straw and grain were separated and washed with deionized water to remove soil and dust particles. After washing, they were air dried at room temperature $\left(25^{\circ} \mathrm{C}\right)$ until they reached a constant weight. The complete root systems, together with adhering soil, of the four rice plants were carefully removed from the soil. The soil was obtained through vigorously shaking the root by hand for 5 min. The rhizosphere soil was collected after removing loosely adhering soil by vigorous shaking. The soil samples were also air dried.

Grain was dehulled in a motorized dehusker (JLGJ4.5, TZYQ, Zhejiang, China) to obtain brown rice. All of the plant samples were milled to fine powder using a blender (Langjia, China). Air-dried soil samples were ground into powder with a mortar and pestle, passed through a $0.15-\mathrm{mm}$ sieve, and then further dried in the oven at $70{ }^{\circ} \mathrm{C}$ until they reached a constant weight. GBW 07602 (GSV-1) rice flour was used as the standard reference material (SRM) for rice grain; GBW07603 (GSV-2) bush twigs and leaves were used as the SRM for rice straw, and GBW 07405 (GSS-4) soil was used as the SRM for soil samples.

\section{Digestion and analysis}

The digestion procedure for all plant material samples followed the protocol of Sun et al. (2010). Briefly, $0.2 \mathrm{~g}$ of rice grain or straw powder was transferred into $50-\mathrm{mL}$ polyethylene centrifuge tubes with $\mathrm{HNO}_{3}(2 \mathrm{~mL})$ added and then incubated overnight at room temperature $\left(\sim 25^{\circ} \mathrm{C}\right)$. Three samples of each SRM (GSV-2) for straw, three SRM of rice flour (GSV1 ), and three blanks were prepared at the same time for quality control. All samples were microwave digested (MARS, Matthew Inc., USA) using the reported temperature program (Sun et al. 2010). Briefly, the temperature was increased to $55^{\circ} \mathrm{C}$ within $5 \mathrm{~min}$ and maintained for $10 \mathrm{~min}$, increased to $75^{\circ} \mathrm{C}$ within $5 \mathrm{~min}$ and maintained for $10 \mathrm{~min}$, and finally increased to $95^{\circ} \mathrm{C}$ within $5 \mathrm{~min}$ and maintained for $30 \mathrm{~min}$. After digestion, the samples were cooled and then diluted to $50 \mathrm{~mL}$ with Millipore ultrapure water (Millipore Milli-Q).

Soil samples $(0.25 \mathrm{~g})$ were weighed into block digestion tubes $(100 \mathrm{~mL})$. In each tube, $5 \mathrm{~mL}$ of aqua regia was added and incubated overnight and then heated at $120{ }^{\circ} \mathrm{C}$ for $12 \mathrm{~h}$. Next, $4 \mathrm{~mL}$ of perchloric acid $\left(\mathrm{HClO}_{4}\right)$ was added to each tube and heated at $140{ }^{\circ} \mathrm{C}$ for $24 \mathrm{~h}$. The cooled digests were filtered and diluted to $50 \mathrm{~mL}$ with Millipore ultrapure water. Two blanks and two samples of SRM for soil (GBW07405) were prepared and digested at the same time for quality control.

Inductively coupled plasma mass spectrometry (ICP-MS, 7500, Agilent Technologies) was used to analyze total As and Cd. Indium (In) was measured as an internal standard and all samples were randomized prior to analysis.

Soil $\mathrm{pH}$ was measured (soil/water ratio of $1 / 2.5$ ) using a Mettler Toledo 320-S pH meter (Mettler Toledo Instruments Co. Ltd. Shanghai, China) with $\mathrm{pH}$ electrode (Inlab HA405DPA, Mettler Toledo Instruments Co. Ltd. Shanghai, China). Soil samples $(2 \mathrm{~g})$ and Millipore ultrapure water $(5 \mathrm{~mL})$ were mixed in a $10-\mathrm{mL}$ centrifuge tube, then agitated $(150 \mathrm{rpm})$ at $25{ }^{\circ} \mathrm{C}$ for $20 \mathrm{~min}$, then left to stand for $30 \mathrm{~min}$. Finally, the electrode of the $\mathrm{pH}$ meter was inserted into the soil and water interface until a constant reading was attained. Fertilizers were milled and sieved through a $0.3-\mathrm{mm}$ sieve, and the $\mathrm{pH}$ values were also measured at a fertilizer/water ratio of $1 / 2.5$. The concentrations of available $\mathrm{Si}$ in fertilizers were measured using the molybdate blue colorimetric method (King et al. 1955). Fertilizer samples ( $0.2 \mathrm{~g})$ were weighed into volumetric flasks $(500 \mathrm{~mL})$. In each flask, $10 \mathrm{~mL}$ of $\mathrm{HCl}(5 \mathrm{~mol} / \mathrm{L})$ was added and diluted to $500 \mathrm{~mL}$ with Millipore ultrapure water and then shaken $(150 \mathrm{rpm})$ for $30 \mathrm{~min}$ at $25^{\circ} \mathrm{C}$. The flasks were left to stand for $30 \mathrm{~min}$ after shaking, then the supernatants $(2.5 \mathrm{~mL})$ were taken to $50-\mathrm{mL}$ centrifuge tubes and $5 \mathrm{~mL}$ of $\mathrm{H}_{2} \mathrm{SO}_{4}(0.3 \mathrm{~mol} / \mathrm{L}), 5 \mathrm{~mL}$ of $\mathrm{N}_{2} \mathrm{H}_{8} \mathrm{MO}_{2} \mathrm{O}_{7}(50 \mathrm{~g} / \mathrm{L}), 5 \mathrm{~mL}$ of $\mathrm{C}_{2} \mathrm{H}_{2} \mathrm{O}_{4}(50 \mathrm{~g} / \mathrm{L})$, and $5 \mathrm{~mL}$ of $\mathrm{FeSO}_{4}(50 \mathrm{~g} / \mathrm{L})$ were sequentially added. The mixture was then diluted to $50 \mathrm{~mL}$ with Millipore ultrapure water. The absorbance at $690 \mathrm{~nm}$ was measured using a spectrophotometer (Beijing Purkinje General Instrument Co, Ltd, China).

\section{Statistical analysis and quality control}

The least square difference (LSD) test was used to compare the means between the different treatments. All statistical analyses were conducted using SPSS 17.0. The As recoveries for rice flour, straw, and soil were 127, 110, and $104 \%$, respectively, while the $\mathrm{Cd}$ recoveries for rice flour, straw, and soil were 106,114 , and $118 \%$, respectively.

\section{Results}

\section{Plant growth and biomass}

In general, fertilizer application significantly improved grain yields and straw biomass relative to the control (Table 2), but no significant differences were observed between the different fertilizer types (including NPK treatments) or their different dosages. Neither grain yield nor straw biomass were 
Table 2 The weight of rice grain and straw biomass under different fertilization regimes $(\mathrm{kg} / \mathrm{ha})$

\begin{tabular}{lllll}
\hline Treatment & Rice grain & Relative yield & Straw biomass & Relative yield \\
\hline Control & $3633 \pm 255 \mathrm{a}$ & 1.00 & $2150 \pm 272 \mathrm{a}$ & 1.00 \\
$\mathrm{NPK}$ & $6734 \pm 368 \mathrm{~b}$ & 1.83 & $4136 \pm 701 \mathrm{~b}$ & 1.92 \\
$\mathrm{NP}+\mathrm{KSi} 900$ & $6738 \pm 298 \mathrm{~b}$ & 1.85 & $3462 \pm 1114 \mathrm{~b}$ & 1.61 \\
$\mathrm{NP}+\mathrm{SKSi} 900$ & $6744 \pm 270 \mathrm{~b}$ & 1.86 & $4144 \pm 919 \mathrm{~b}$ & 1.93 \\
$\mathrm{NP}+\mathrm{SKSi} 9000$ & $6492 \pm 424 \mathrm{~b}$ & 1.79 & $4333 \pm 364 \mathrm{~b}$ & 2.02 \\
$\mathrm{NPK}+\mathrm{Na}_{2} \mathrm{SiO}_{3} 900$ & $7077 \pm 465 \mathrm{~b}$ & 1.95 & $3441 \pm 1030 \mathrm{~b}$ & 1.60 \\
$\mathrm{NPK}+\mathrm{SiCa} 900$ & $7262 \pm 496 \mathrm{~b}$ & 2.00 & $4646 \pm 962 \mathrm{~b}$ & 2.16 \\
$\mathrm{NPK}+\mathrm{SiCa} 9000$ & $6924 \pm 464 \mathrm{~b}$ & 1.91 & $3922 \pm 481 \mathrm{~b}$ & 1.82 \\
$\mathrm{NPK}+\mathrm{RS}$ & $6944 \pm 177 \mathrm{~b}$ & 1.91 & $4300 \pm 544 \mathrm{~b}$ & 2.00 \\
\hline
\end{tabular}

$\mathrm{RS}, \mathrm{CaSi}, \mathrm{KSi}, \mathrm{S}-\mathrm{KSi}$, and $\mathrm{Na}_{2} \mathrm{SiO}_{3}$ represent rice straw, Si-calcium fertilizer, Si-potash fertilizer, semi-finished product of Si-potash fertilizer, and sodium metasilicate fertilizer, respectively. Different letters indicate significant differences at $p<0.05$ significantly increased following treatments with Si fertilizers in our experiment when compared with the NPK treatment, although it is well known that Si fertilizers can promote plant growth which has been observed in many plants, including peanut, maize, and cucumber (Zhu et al. 2004; Da Cunha and Do Nascimento 2009; Shi et al. 2010). This may be because not enough available $\mathrm{Si}$ was added to the soil to significantly influence grain yield and straw biomass or the amount of available $\mathrm{Si}$ in the soil is already high enough for rice growth.

\section{Arsenic concentration in grain and straw}

The average As contents of the rice samples from the control and NPK treatment were $0.45 \pm 0.13$ and $0.41 \pm 0.08 \mathrm{mg} / \mathrm{kg}$, respectively, higher than the food standard As limit $(0.2 \mathrm{mg} / \mathrm{kg}$ ) for rice in China (GB2762-2012). NPK and $\mathrm{NPK}+\mathrm{RS}$ treatments significantly increased As concentration in grain by 12.6 and $26.4 \%$, respectively, with a corresponding As concentration increase in rice straw of 15.9 and $20.5 \%$, respectively (Fig. 1a). Total As concentration was significantly decreased in the NP+S-KSi9000 treatment by as much as 29.1 and $32.4 \%$ relative to the NPK treatment and by 20.1 and $21.6 \%$ relative to the control for rice grain and straw, respectively. The NPK $+\mathrm{CaSi} 9000$ and NP+S-KSi900 treatments also substantially reduced total As in rice grain by 22.4 and $20.1 \%$ relative to the NPK treatment and by 12.6 and $10.1 \%$ relative to control for rice grain and straw, respectively. The high Si amendments (9000 kg/ha) substantially decreased the rice As concentration relative to the low $\mathrm{Si}$ amendments (900 kg/ha). Of all the Si fertilizers utilized, the semi-finished product of Si-potash fertilizer achieved the best As reduction in rice. While the other $\mathrm{Si}$ amendments $(900 \mathrm{~kg} / \mathrm{ha}) \mathrm{did}$ not significantly decrease As concentration in rice grain, the treatment of NP+S-KSi reduced As by $20.1 \%$ relative to NPK. The As concentration in rice grain is closely related to that in straw $\left(R^{2}=0.82\right)$ (Fig. 1b), indicating that Si fertilizers significantly reduce the As concentration in straw.

\section{Cadmium concentration in rice grain and straw}

The Cd contents in rice samples from the control and NPK treatments were $0.70 \pm 0.11$ and $0.69 \pm 0.08 \mathrm{mg} / \mathrm{kg}$, respective$\mathrm{ly}$, and exceeded the national food standard limit of $0.2 \mathrm{mg} / \mathrm{kg}$
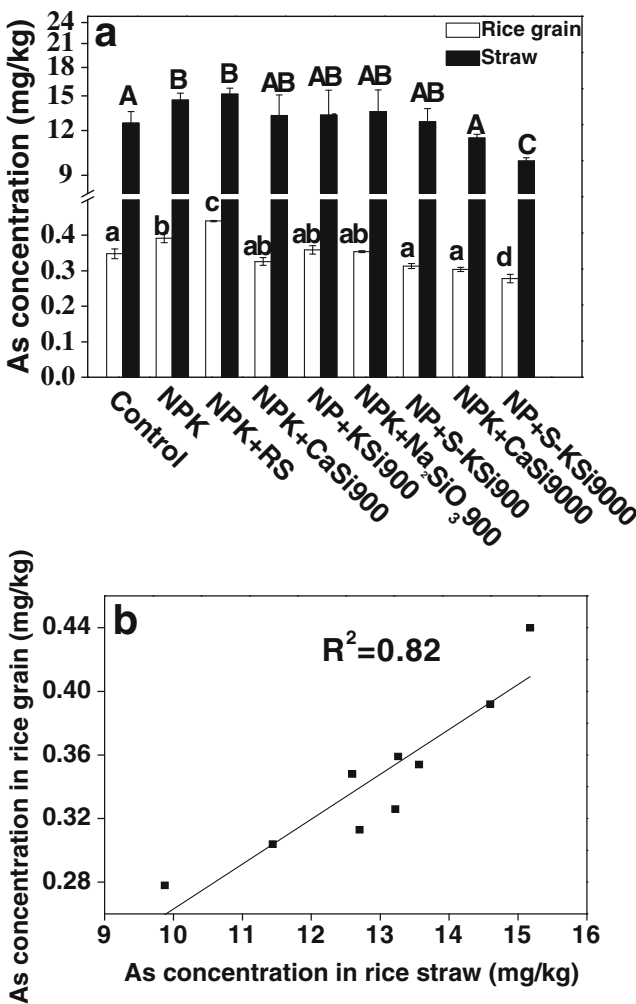

Fig. 1 Arsenic concentrations in rice grain and straw (dry weight) (a), and the correlation coefficient $\left(R^{2}\right)$ between them under different $\mathrm{Si}$ fertilizers and dosages (b). RS, CaSi, KSi, S-KSi, and $\mathrm{Na}_{2} \mathrm{SiO}_{3}$ represent rice straw, $\mathrm{Si}$-calcium fertilizer, Si-potash fertilizer, semifinished product of Si-potash fertilizer, and sodium metasilicate fertilizer, respectively. Different letters above bars indicate difference at $p<0.05$ ( $A-C$ represent significant differences between different treatments for rice straw, and $a-d$ represent significant differences between different treatments for rice grain) 
Cd for rice in China (GB2762-2012). All Si fertilizers significantly reduced $\mathrm{Cd}$ concentration in rice grain and straw, except for $\mathrm{Na}_{2} \mathrm{SiO}_{3}$ (Fig. 2a). The capacity of different $\mathrm{Si}$ fertilizers to reduce $\mathrm{Cd}$ concentration in rice grain decreased in the following order: $\mathrm{NPK}+\mathrm{CaSi} 9000(71.5 \%)>\mathrm{NPK}+\mathrm{CaSi} 900$ $(48.0 \%)>\mathrm{NP}+\mathrm{S}-\mathrm{KSi} 9000(42.0 \%)>\mathrm{NP}+\mathrm{KSi} 900$ $(40.0 \%)>\mathrm{NP}+\mathrm{S}-\mathrm{KSi} 900(26.5 \%)>\mathrm{NPK}+\mathrm{RS}(23.1 \%)$. High $\mathrm{Si}(9000 \mathrm{~kg} / \mathrm{ha}$ ) application decreased the grain Cd more than the corresponding low $\mathrm{Si}$ amendments $(900 \mathrm{~kg} / \mathrm{ha})$. The most effective treatment was $\mathrm{NPK}+\mathrm{CaSi} 9000$ treatment, which reduced the total $\mathrm{Cd}$ in rice grain and straw by 71.5 and $76.7 \%$, respectively (Fig. 2a). At the normal level of Si application $(900 \mathrm{~kg} / \mathrm{ha})$, CaSi fertilizer exhibited a higher ability to reduce grain $\mathrm{Cd}$ than other $\mathrm{Si}$ fertilizers, even though the available $\mathrm{Si}$ in the CaSi fertilizer is less than that in KSi fertilizer. Similarly to As, a close linear relationship was observed between the $\mathrm{Cd}$ concentration in rice grain and straw $\left(R^{2}=0.85\right)$ (Fig. 2b). This suggests that transfer coefficients from straw to grain are similar, and absorption of $\mathrm{Cd}$ from roots may be important for reducing rice $\mathrm{Cd}$.
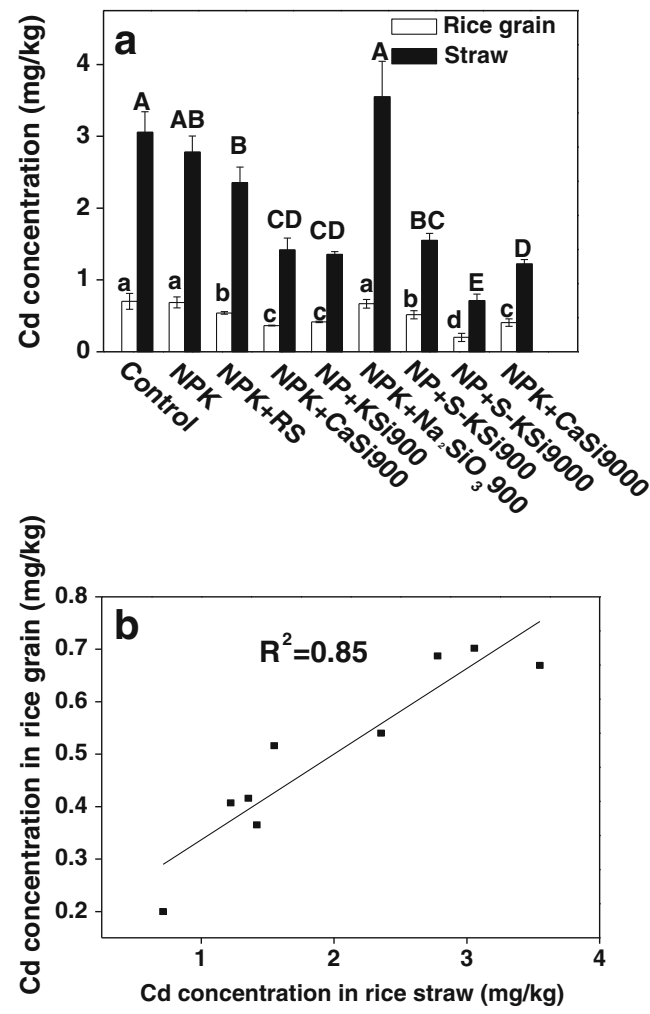

Fig. $2 \mathrm{Cd}$ concentration in the rice grain and straw (dry weight) (a), and the correlation coefficient $\left(R^{2}\right)$ between them under different Si fertilizers and dosages (b). RS, CaSi, $\mathrm{KSi}, \mathrm{S}-\mathrm{KSi}$, and $\mathrm{Na}_{2} \mathrm{SiO}_{3}$ represent rice straw, $\mathrm{Si}$-calcium fertilizer, Si-potash fertilizer, semi-finished product of $\mathrm{Si}$ potash fertilizer, and sodium metasilicate fertilizer, respectively. Different letters above bars indicate difference at $p<0.05$ ( $A-E$ represent significant differences between different treatments for rice straw, and $a-d$ represent significant differences between different treatments for rice grain)

\section{The changes of $\mathrm{pH}$ in soil after Si fertilization}

The soil $\mathrm{pH}$ substantially affects the bioavailability of As and $\mathrm{Cd}$ and their absorption by plants (Reddy and Patrick 1977; Masscheleyn et al. 1991; Marin et al. 1993; Naidu et al. 1994; Chan et al. 2008). The soil was slightly acidic with $\mathrm{pH} 6.0$ (Table 3). Application of Si fertilizers increased the $\mathrm{pH}$ values of soil except in the case of the RS treatment, and the highest $\mathrm{pH}$ was shown in the NPK $+\mathrm{CaSi} 9000$ treatment $(p<0.01)$ and the NP+S-KSi9000 treatment $(p<0.05)$ (Table 3$)$. The $\mathrm{pH}$ value increased substantially with increased Si fertilizer application rate, which is reasonable because all applied Si fertilizers have high $\mathrm{pH}$ in the range of 9.9-11.9 (Table 4).

\section{Discussion}

\section{Effect of $\mathrm{Si}$ on As concentration in rice grain}

Several Si fertilizers were investigated to reduce As accumulation in rice grain in the field, and differences were observed in these effects between fertilizer types. Compared with the NPK treatment, NP+S-KSi900, NP+S-KSi9000, and NPK+ CaSi9000 treatments significantly reduced As concentration in rice grain. This inhibitory effect of $\mathrm{Si}$ is supported by many laboratory experiments (Bogdan and Schenk 2008; Li et al. 2009; Fleck et al. 2013; Tripathi et al. 2013). Areao et al. (2009) reported that the soil Eh value decreased rapidly during the flooded period. In this case, arsenite as the predominant form of As species in paddy soils (reducing environments) is actually present in solution predominantly as an undissociated molecule at $\mathrm{pH}<8$. This is because $\mathrm{pKa}$ of arsenous acid $\left(\mathrm{As}(\mathrm{OH})_{3}\right)$ is 9.22 , which is similar to the value for silicic acid

Table 3 The soil $\mathrm{pH}$ under different treatments

\begin{tabular}{ll}
\hline Treatment & pH value \\
\hline Control & $6.00 \pm 0.23 \mathrm{a}$ \\
$\mathrm{NPK}$ & $5.99 \pm 0.17 \mathrm{a}$ \\
$\mathrm{NP}+\mathrm{KSi} 900$ & $6.48 \pm 0.23 \mathrm{a}$ \\
$\mathrm{NP}+\mathrm{SKSi900}$ & $6.30 \pm 0.11 \mathrm{a}$ \\
$\mathrm{NP}+\mathrm{SKSi} 9000$ & $6.59 \pm 0.21 \mathrm{~b}$ \\
$\mathrm{NPK}+\mathrm{Na}_{2} \mathrm{SiO}_{3} 900$ & $6.10 \pm 0.14 \mathrm{a}$ \\
$\mathrm{NPK}+\mathrm{CaSi} 900$ & $6.11 \pm 0.11 \mathrm{a}$ \\
$\mathrm{NPK}+\mathrm{CaSi} 9000$ & $6.71 \pm 0.08 \mathrm{~b}$ \\
$\mathrm{NPK}+\mathrm{RS}$ & $5.78 \pm 0.41 \mathrm{a}$ \\
\hline
\end{tabular}

$\mathrm{RS}, \mathrm{CaSi}, \mathrm{KSi}, \mathrm{S}-\mathrm{KSi}$, and $\mathrm{Na}_{2} \mathrm{SiO}_{3}$ represent rice straw, Si-calcium fertilizer, Sipotash fertilizer, semi-finished product of Si-potash fertilizer, and sodium metasilicate fertilizer, respectively. Different letters indicate significant differences at $p<0.05$ 
Table 4 The $\mathrm{pH}$ and available $\mathrm{Si}$ in $\mathrm{Si}$ fertilizers

\begin{tabular}{lrr}
\hline Fertilizer type & $\mathrm{pH}$ value & $\mathrm{SiO}_{2}(\%)$ \\
\hline $\mathrm{KSi}$ & $9.9 \pm 0.2$ & $31.0 \pm 1.5$ \\
$\mathrm{SKSi}$ & $10.2 \pm 0.1$ & $23.3 \pm 0.4$ \\
$\mathrm{Na}_{2} \mathrm{SiO}_{3}$ & $11.9 \pm 0.1$ & $13.2 \pm 0.9$ \\
$\mathrm{CaSi}$ & $10.1 \pm 0.1$ & $24.2 \pm 0.6$ \\
\hline
\end{tabular}

RS, CaSi, KSi, S-KSi, $\mathrm{Na}_{2} \mathrm{SiO}_{3}$ represent rice straw, Si-calcium fertilizer, Si-potash fertilizer, semi-finished product of Sipotash fertilizer, sodium metasilicate fertilizer, respectively

( $\mathrm{pKa}$ of 9.3). Both molecules are tetrahedral with similar sizes (Raven et al. 1998), so arsenite uptake shares the Si pathway of entry to root cells and transfer towards the xylem (Zhao et al. 2009). Additional Si, originated from Si fertilizers, increased the bioavailability of $\mathrm{Si}$. It competed with arsenite, and thus mitigated As absorption in rice and decreased the As contents in rice straw, followed by a decreased As level in rice grain (Fig. 1), especially with large amounts amendments of Si fertilizers (9000 kg/ha) (Fig. 1).

NPK application also clearly increased As level in rice grain $(12.6 \%)$. NPK fertilizers are normally applied into the soils to increase crop yield. The As concentration in basal fertilizers (NPK) is low $(0.03-5.2 \mathrm{mg} / \mathrm{kg})$, suggesting the increase of As in grain is not due to the application of basal fertilizers. The most plausible explanations are (a) the competition between phosphate $\left(\mathrm{PO}_{4}{ }^{2-}\right)$ originating from the NPK fertilizers and arsenate in the soil may release As into pore water (Peryea and Kammereck 1997; Peryea 1998; Wang et al. 2002), leading to increased As bioavailability and higher uptake of As by the plants, or (b) the NPK fertilizers may stimulate microbial activity, which reduces Fe or As in soil, releasing the As adsorbed on the Fe minerals and causing increased availability of As. The addition of rice straw into the soil $(\mathrm{NPK}+\mathrm{RS})$ significantly increased the As concentration in rice grain by 12.2 and $26.4 \%$ compared with the NPK and control treatments, respectively. There are two possible explanations for this result. Firstly, the rice straw contained high level of As that can be released into soil through decomposition. The released As is bioavailable and causes higher As accumulation in rice grain. Secondly, the organic matter released from rice straw decomposition facilitated the reduction of Fe/hydroxides in the soil, and As that had been bonded within the $\mathrm{Fe}$ /hydroxides was released into the pore water, thus increasing available As in soil and counteracting the $\mathrm{Si}$ inhibitory effect (Shuman 1985).

In comparison with the high rate of Si fertilization $(9000 \mathrm{~kg} / \mathrm{ha})$, the normal level of Si fertilization $(900 \mathrm{~kg} / \mathrm{ha})$ did not significantly reduce the As concentration in rice grain, except in the case of S-KSi. Interestingly, this occurs despite the fact that the available $\mathrm{Si}$ in $\mathrm{KSi}$ is about 1.3 times higher than $\mathrm{S}-\mathrm{KSi}$, and the reduction effect of $\mathrm{S}-\mathrm{KSi} 9000$ was greater

than CaSi9000, even though the content of available $\mathrm{Si}$ in S$\mathrm{KSi}$ is similar to CaSi. Therefore, the $\mathrm{S}-\mathrm{KSi}$ is most effective for reducing As concentration in rice grain. We will investigate this finding more deeply in future research.

\section{Effect of Si on Cd concentration in rice grain}

All Si fertilizers except $\mathrm{Na}_{2} \mathrm{SiO}_{3}$ significantly reduce $\mathrm{Cd}$ concentration in rice grain, and the transfer coefficient from straw to rice grain is similar $\left(R^{2}=0.85\right)$. The NPK + CaSi9000 treatment showed the greatest decrease in the rice $\mathrm{Cd}$ concentration (up to $\sim 73 \%$ ). These results were partially because of $\mathrm{Cd}$ immobilization caused by silicateinduced $\mathrm{pH}$ change in the soils, the increase of $\mathrm{pH}$ (Table 3), which altered the $\mathrm{Cd}$ distribution in soil fractions, reduced the phytoavailable $\mathrm{Cd}$, and increased the allocation of metals into more stable fractions (Naidu et al. 1994; Liang et al. 2005; 2007). This resulted in the observed significant decrease of $\mathrm{Cd}$ concentration in straw and grain. This supports other studies that showed that slag alkaline Si-containing materials at high dosages can induce an increase in soil $\mathrm{pH}$ which consequently increases the proportion of non-exchangeable heavy metals (Chen et al. 2000; Li et al. 2012). Another possible explanation is that $\mathrm{Si}$ restricted the transport of $\mathrm{Cd}$ from roots to shoots. In rice plants, Si plays an important role as a structural component of the cell wall; Si-mediated formation of colloidal silica in the cell walls has a strong affinity to heavy metals, and $\mathrm{Cd}$ is mainly deposited in cell walls through the co-precipitation of $\mathrm{Cd}$ and $\mathrm{Si}$ (Epstein 1999; Wang et al. 2000; Shi et al. 2010). The co-precipitation of $\mathrm{Cd}$ and $\mathrm{Si}$ in cell walls via Si-wall$\mathrm{Cd}$ complexation may be one of the key target mechanisms for the reduction of $\mathrm{Cd}$ transportation from roots to shoots and thus the mitigation of $\mathrm{Cd}$ accumulation in rice grain. Furthermore, Si deposition in the vicinity of the endodermis can partially block the apoplast bypassflow across the roots and inactivate $\mathrm{Cd}$ apoplastic transport from roots to shoots (Shi et al. 2005).

Clearly, the mitigation of $\mathrm{Cd}$ accumulation by $\mathrm{Si}$ fertilizers is more effective for rice grain than the mitigation of As accumulation, with the greatest reduction percentage about $20 \%$ for As and $72 \%$ for Cd. As shown in Fig. 2, the CaSi fertilizer is the most effective for $\mathrm{Cd}$ reduction in rice grain, while the $\mathrm{S}$ $\mathrm{KSi}$ is the most effective for As reduction. Several studies have shown that access via $\mathrm{Ca}^{2+}$ transporters is one of the main molecular pathways of $\mathrm{Cd}^{2+}$ uptake into plant cells (Clemens 2006; Verbruggen et al. 2009). Therefore, the reduced $\mathrm{Cd}$ concentration in rice grain after addition of $\mathrm{CaSi}$ fertilizer may indicate that $\mathrm{Ca}$ plays a role as antagonist in $\mathrm{Cd}$ uptake mechanisms. This may explain why $\mathrm{CaSi}$ fertilizer is much more effective than $\mathrm{KSi}$ fertilizer for $\mathrm{Cd}$ mitigation in rice. 


\section{Conclusions}

Most Si fertilizers can successfully reduce $\mathrm{Cd}$ and As concentration in the rice grain grown on paddy soils polluted with heavy metals. Different Si fertilizers have different effects on the reduction of $\mathrm{As}$ and $\mathrm{Cd}$ concentrations in rice grain. The $\mathrm{S}$ $\mathrm{KSi}$ fertilizer is the most effective for As reduction, while $\mathrm{CaSi}$ fertilizer is the optimal choice for $\mathrm{Cd}$ mitigation in rice grain. This study shows that application of Si fertilizers can be effective in reducing the As and $\mathrm{Cd}$ concentrations in rice grain and thus reducing the health risk for people living in the heavy metal-contaminated area.

Acknowledgments This project was financially supported by the Natural Science Foundation of China (No. 41371459), the State Key Program of Natural Science Foundation of China (No. 41330853), the Special Fund for Agro-scientific Research in the Public Interest of China (201503122), and the National High Technology Research and Development Program of China (863 Program, 2013AA06A209).

\section{References}

Areao T, Kawasaki A, Baba K, Mori S, Matsumoto S (2009) Effects of water management on cadmium and arsenic accumulation and dimethylarsinic acid concentrations in Japanese rice. Environ Sci Technol 43:9361-9367

Bernard A, Lauwerys R (1986) Effects of cadmium exposure in humans. Cadmium, Springer, New York, In, pp 135-177

Bogdan K, Schenk MK (2008) Arsenic in rice (Oryza sativa L.) related to dynamics of arsenic and silicic acid in paddy soils. Environ Sci Technol 42(21):7885-7890

Chan K, Van Zwieten L, Meszaros I, Downie A, Joseph S (2008) Agronomic values of greenwaste biochar as a soil amendment. Soil Res 45(8):629-634

Chen HM, Zheng CR, Tu C, Shen ZG (2000) Chemical methods and phytoremediation of soil contaminated with heavy metals. Chemosphere 41(1):229-234

Clemens S (2006) Toxic metal accumulation, responses to exposure and mechanisms of tolerance in plants. Biochimie 88(11):1707-1719

Clemens S, Aarts MG, Thomine S, Verbruggen N (2013) Plant science: the key to preventing slow cadmium poisoning. Trends Plant Sci 18: 92-99

Da Cunha KPV, Do Nascimento CWA (2009) Silicon effects on metal tolerance and structural changes in maize (Zea mays L.) grown on a cadmium and zinc enriched soil. Water Air Soil Pollut 197(1-4): 323-330

Drees LR, Wilding LP, Smeck NE, Senkayi AL (1989) Silica in soils: quartz and disordered silica polymorphs. Minerals in Soil Environments (mineralsinsoile):913-974

Epstein E (1994) The anomaly of silicon in plant biology. Proc Natl Acad Sci U S A 91(1):11-17

Epstein E (1999) Silicon. Annu Rev Plant Biol 50(1):641-664

Fleck AT, Mattusch J, Schenk MK (2013) Silicon decreases the arsenic level in rice grain by limiting arsenite transport. J Plant Nutr Soil Sci 176(5):785-794

Fraysse F, Pokrovsky OS, Schott J, Meunier J-D (2006) Surface properties, solubility and dissolution kinetics of bamboo phytoliths. Geochim Cosmochim Acta 70(8):1939-1951

GB15618-1995. Environmental quality standard for soils. National Standards of the People's Republic of China
GB2762-2012. Maximum levels of contaminants in food. Chinese Food Standards Agency

Guo W, Zhu Y-G, Liu W-J, Liang Y-C, Geng C-N, Wang S-G (2007) Is the effect of silicon on rice uptake of arsenate (AsV) related to internal silicon concentrations, iron plaque and phosphate nutrition? Environ Pollut 148:251-257

Guo W, Zhang J, Teng M, Wang LH (2009) Arsenic uptake is suppressed in a rice mutant defective in silicon uptake. J Plant Nutr Soil Sci 172(6):867-874

Halim M, Majumder R, Nessa S, Hiroshiro Y, Uddin M, Shimada J, Jinno K (2009) Hydrogeochemistry and arsenic contamination of groundwater in the Ganges Delta Plain, Bangladesh. J Hazard Mater 164(2):1335-1345

Kim Y-H, Khan AL, Kim D-H, Lee S-Y, Kim K-M, Waqas M, Jung H-Y, Shin J-H, Kim J-G, Lee I-J (2014) Silicon mitigates heavy metal stress by regulating P-type heavy metal ATPases, Oryza sativa low silicon genes, and endogenous phytohormones. BMC Plant Biol 14(1):13

King E, Stacy B, Holt P, Yates DM, Pickles D (1955) The colorimetric determination of silicon in the micro-analysis of biological material and mineral dusts. Analyst 80(951):441-453

Li R-Y, Stroud JL, Ma J-F, McGrath SP, Zhao F-J (2009) Mitigation of arsenic accumulation in rice with water management and silicon fertilization. Environ Sci Technol 43(10):3778-3783

Li L, Zheng C, Fu Y, Wu D, Yang X, Shen H (2012) Silicate-mediated alleviation of $\mathrm{Pb}$ toxicity in banana grown in Pb-contaminated soil. Biol Trace Elem Res 145(1):101-108

Liang Y-C (1999) Effects of silicon on enzyme activity and sodium, potassium and calcium concentration in barley under salt stress. Plant and Soil 209(2):217-224

Liang Y-C, Wong J, Wei L (2005) Silicon-mediated enhancement of cadmium tolerance in maize (Zea mays L.) grown in cadmium contaminated soil. Chemosphere 58(4):475-483

Liang Y-C, Sun W, Zhu Y-G, Christie P (2007) Mechanisms of siliconmediated alleviation of abiotic stresses in higher plants: a review. Environ Pollut 147(2):422-428

Ma J-F, Miyake Y, Takahashi E (2001) Silicon as a beneficial element for crop plants. Stud Plant Sci 8:17-39

Marin A, Masscheleyn P, Patrick WH Jr (1993) Soil redox-pH stability of arsenic species and its influence on arsenic uptake by rice. Plant and Soil 152(2):245-253

Marmiroli M, Pigoni V, Savo-Sardaro ML, Marmiroli N (2014) The effect of silicon on the uptake and translocation of arsenic in tomato (Solanum lycopersicum L.). Environ Exp Bot 99:9-17

Marschner H, Rimmington G (1988) Mineral nutrition of higher plants. Plant Cell Environ 11:147-148

Masscheleyn PH, Delaune RD, Patrick WH Jr (1991) Effect of redox potential and $\mathrm{pH}$ on arsenic speciation and solubility in a contaminated soil. Environ Sci Technol 25(8):1414-1419

Meharg C, Meharg AA (2015) Silicon, the silver bullet for mitigating biotic and abiotic stress, and improving grain quality, in rice? Environ Exp Bot 120:8-17

Meharg AA, Williams PN, Adomako E, Lawgali YY, Deacon C, Villada A, Cambell RC, Sun G-X, Zhu Y-G, Feldmann J (2009) Geographical variation in total and inorganic arsenic content of polished (white) rice. Environ Sci Technol 43(5):1612-1617

Naidu R, Bolan NS, Kookana RS, Tiller K (1994) Ionic-strength and pH effects on the sorption of cadmium and the surface charge of soils. Eur J Soil Sci 45(4):419-429

Ng JC, Wang J, Shraim AA (2003) Global health problem caused by arsenic from natural sources. Chemosphere 52(9):1353-1359

Peryea FJ (1998) Phosphate starter fertilizer temporarily enhances soil arsenic uptake by apple trees grown under field conditions. Hortscience 33(5):826-829 
Peryea FJ, Kammereck R (1997) Phosphate-enhanced movement of arsenic out of lead arsenate-contaminated topsoil and through uncontaminated subsoil. Water Air Soil Pollut 93(1-4):243-254

Putwattana N, Kruatrachue M, Pokethitiyook P, Chaiyarat R (2010) Immobilization of cadmium in soil by cow manure and silicate fertilizer, and reduced accumulation of cadmium in sweet basil (Ocimum basilicum). Science Asia 36(4):349-354

Raven KP, Jain A, Loeppert RH (1998) Arsenite and arsenate adsorption on ferrihydrite: kinetics, equilibrium, and adsorption envelopes. Environ Sci Technol 32(3):344-349

Reddy C, Patrick W (1977) Effect of redox potential and $\mathrm{pH}$ on the uptake of cadmium and lead by rice plants. J Environ Qual 6(3): 259-262

Seyfferth AL, Fendorf S (2012) Silicate mineral impacts on the uptake and storage of arsenic and plant nutrients in rice (Oryza sativa L.). Environ Sci Technol 46(24):13176-13183

Shi X, Zhang C, Wang H, Zhang F (2005) Effect of Si on the distribution of Cd in rice seedlings. Plant and Soil 272(1-2):53-60

Shi G, Cai Q, Liu C, Wu L (2010) Silicon alleviates cadmium toxicity in peanut plants in relation to cadmium distribution and stimulation of antioxidative enzymes. Plant Growth Regul 61(1):45-52

Shuman L (1985) Fractionation method for soil microelements. Soil Sci 140(1):11-22

Sun Y, Li Z, Guo B, Chu G, Wei C, Liang Y-C (2008) Arsenic mitigates cadmium toxicity in rice seedlings. Environ Exp Bot 64(3):264-270

Sun G-X, Liu X, Williams PN, Zhu Y-G (2010) Distribution and translocation of selenium from soil to grain and its speciation in paddy rice (Oryza sativa L.). Environ Sci Technol 44(17):6706-6711
Sun G-X, Van de Wiele T, Alava P, Tack F, Du Laing G (2012) Arsenic in cooked rice: Effect of chemical, enzymatic and microbial processes on bioaccessibility and speciation in the human gastrointestinal tract. Environ Pollut 162:241-246

Tripathi P, Tripathi RD, Singh RP, Dwivedi S, Goutam D, Shri M, Chakrabarty D (2013) Silicon mediates arsenic tolerance in rice (Oryza sativa L.) through lowering of arsenic uptake and improved antioxidant defence system. Ecol Eng 52:96-103

Verbruggen N, Hermans C, Schat H (2009) Mechanisms to cope with arsenic or cadmium excess in plants. Curr Opin Plant Biol 12(3): 364-372

Wang L, Wang Y, Chen Q, Cao W, Li M, Zhang F (2000) Silicon induced cadmium tolerance of rice seedlings. J Plant Nutr 23(10):1397-1406

Wang J, Zhao FJ, Meharg AA, Raab A, Feldmann J, McGrath SP (2002) Mechanisms of arsenic hyperaccumulation in Pteris vittata. Uptake kinetics, interactions with phosphate, and arsenic speciation. Plant Physiol 130(3):1552-1561

Williams PN, Lei M, Sun G-X, Huang Q, Lu Y, Deacon C, Meharg AA, Zhu Y-G (2009) Occurrence and partitioning of cadmium, arsenic and lead in mine impacted paddy rice: Hunan, China. Environ Sci Technol 43(3):637-642

Zhang C, Wang L, Nie Q, Zhang W, Zhang F (2008) Long-term effects of exogenous silicon on cadmium translocation and toxicity in rice (Oryza sativa L.). Environ Exp Bot 62(3):300-307

Zhao F-J, Ma J-F, Meharg AA, McGrath SP (2009) Arsenic uptake and metabolism in plants. New Phytol 181(4):777-794

Zhu Z, Wei G, Li J, Qian Q, Yu J (2004) Silicon alleviates salt stress and increases antioxidant enzymes activity in leaves of salt-stressed cucumber (Cucumis sativus L.). Plant Sci 167(3):527-533 